\title{
Syninclusions of the Eocene winter ant Prenolepis benschei (Hymenoptera: Formicidae) and Germaraphis aphids (Hemiptera: Eriosomatidae) in the Late Eocene Baltic and Rovno ambers: some implications
}

\section{Сининкаюзы эоџенового зимнего муравья Prenolepis benschei (Hymenoptera: Formicidae) и тлей Germaraphis (Hemiptera: Eriosomatidae) в позднеэоџеновых балтийском и ровенском янтарях: некоторые выводы}

\author{
E.E. Perkovsky \\ Е.Э. Перковский
}

Schmalhausen Institute of Zoology, National Academy of Sciences of Ukraine, B. Khmelnitsky Str. 15, Kiev 01601, Ukraine. E-mail: perkovsky@fromru.com

Институт зоологии им. И.И. Шмальгаузена НАН Украины, ул. Б. Хмельницкого, 15, Киев 01601, Украина.

KEY WORDS: syninclusions, Aphidinea, Formicidae, Eocene, amber, Ukraine, Russia, Denmark, niche separation.

КЛЮЧЕВЫЕ СЛОВА: сининклюзы, Aphidinea, Formicidae, эоцен, янтарь, Украина, Россия, Дания, дивергенция экологических ниш.

ABSTRACT. Prenolepis-Germaraphis syninclusions are reported for the first time from the Baltic and Rovno ambers. The number of syninclusions of those taxa in the representative Kalandyk collection of the Baltic amber (half of all samples with Prenolepis) indicates close lifetime relationship between Germaraphis and Prenolepis. We hypothesize that ants Prenolepis henschei were not dendrobiotic, i.e. they foraged on the resin-producing trees mainly looking for homopterans, particularly aphids which they did not keep in their nests. The relationship between $P$. henschei and Germaraphis was not obligatory since it depended on the abundance of the aphids. Activity of the resin traps in the amber forests is supposed to be time-limited, and we hypothesize that the resin traps in the Baltic amber forest were active at lower temperatures if compared to the forests that produced the Scandinavian and Rovno ambers. This hypothesis explains the low proportion of workers and the high numbers of sexuals of $P$. henschei in the Scandinavian and Rovno ambers as compared to the Baltic one.

РЕЗЮМЕ. Сининклюзы Prenolepis и Germaraphis впервые найдены в балтийском и ровенском янтаре. Число сининклюзов этих таксонов (половина всех образцов с Prenolepis) в репрезентативной коллекции Каландыка (балтийский янтарь) указывает на тесную прижизненную связь Germaraphis и Prenolepis. Мы предполагаем, что муравьи Prenolepis henschei не были дендробионтами: они лишь фуражировали на деревьях, производящих смолу, главным образом в поисках равнокрылых, в частности, тлей, которых они не держали в своих гнездах. Отношения P. henschei и Germaraphis не были облигатными и зависели от численности тлей. Предполагается, что активность смоляных ловушек в янтарных лесах была ограничена во времени, и в балтийском янтарном лесу смоляные ловушки начинали действовать при более низких температурах, чем в лесах, послуживших источниками скандинавского и ровенского янтарей. Эта гипотеза объясняет низкую долю рабочих и многочисленность крылатых муравьев в скандинавском и ровенском янтарях по сравнению с балтийским.

\section{Introduction}

The term "syninclusions" was coined by the famous Polish entomologist Jan Koteja who predicted the key role of multiple organic inclusions in the same pieces of amber for understanding the biotic structure of past environments [Koteja, 1989]. The significance of syninclusion analysis as one of the key ways of revealing the structure of biocenoses of the fossil forests is becoming more obvious now [Kutscher, Koteja, 2000; Sontag, 2003; Perrichot, Girard, 2009; Weitschat, 2009; Wichard, 2009; Rasnitsyn, 2011].This work follows our previous studies in this field (summarized in [Perkovsky et al., 2010a]) based mainly on the inclusions in the Rovno amber, a southern coeval analog of the Baltic amber with the same age of origin 
(see reviews in [Perkovsky et al., 2007, 2010b] for details).

Previous studies have shown that composition of the inclusions depended on the weight (= size) of the pieces of amber [Perkovsky, 2009]. It was demonstrated, for example, that the specialized dendrobiotic ants, like Ctenobethylus goepperti (Mayr, 1868), occupied a higher proportion of the ant assemblage in smaller pieces of amber (net weight less than $1.5 \mathrm{~g}$ ) than in the larger ones, while the more generalist (mainly herpetobiotic) ants, Lasius schiefferdeckeri Mayr, 1868, showed an opposite tendency. The larger pieces of amber are, the higher is the probability that they have originated from the trunk and not from thin branches of the amber tree. The above mentioned trend could therefore be explained by the situation when $C$. goepperti was a frequent visitor to the tree crown, whereas L. schiefferdeckeri was probably more or less restricted to trunks and perhaps also to thick branches.

Distribution of families of the order Diptera is found to depend on the weight of the pieces of amber as well [Perkovsky et al., 2010a]. We can generally infer that small pieces were widely distributed over the amber tree and they served as better traps than the larger ones for both insects of the air plankton as well as other arthropods which are not confined to tree trunks.

Syninclusions of ants and the dominant aphid, the longbeaked aphids Germaraphis Heie, 1967 are of particular interest, since modern analogs of Germaraphis, i.e. aphids of the genus Stomaphis Walker, 1870, are obligate ant symbionts [Heie, Wegierek, 2009]. The proportion of Germaraphis among all insect inclusions of the different weight fractions of the Rovno amber reveals the same pattern. For the larger pieces (with the net weight not less than $6.5 \mathrm{~g}$ ), Germaraphis comprises $2.9 \%$ of all insects identified to the order level (excluding Entognatha), and the corresponding share is only $1.45 \%$ for the smaller pieces. Basing on the same material, worker ants occupy $4.4 \%$ of all insects (excluding Entognatha) in the larger pieces, and $6.2 \%$ in the smaller ones [Perkovsky, 2010]. At present, this pattern cannot be unequivocally explained by the presence or absence of particular species of amber ants, except that $C$. goepperti occupies $1.2 \%$ of all insects in the larger pieces, and $2.3 \%$ in the smaller ones, while the proportion of L. schiefferdeckeri in the larger pieces is slightly higher than that in the smaller ones [Perkovsky, 2010].

\section{Material and methods}

The collection of the Baltic amber from the East Coast of the Bay of Gdańsk (Sambia) donated by Wojciech Kalandyk to the Museum of Amber Inclusions at the Department of Invertebrate Zoology, University of Gdańsk [Sontag, 2003] was examined. The Kalandyk collection mainly contains large pieces of amber. Specifically, only 1824 pieces with zooinclusions, approximately one third weights less than $10 \mathrm{~g}$
[Sontag, pers. comm.]. Ant-aphid syninclusions were studied in the Rovno amber collection of Schmalhausen Institute of Zoology of the National Academy of Sciences of Ukraine, Kiev (SIZK) as well. Photographs were taken at the Paleontological Institute, Russian Academy of Sciences (Moscow) using the microscopes Leica MZ 16 and Leica M 165.

The statistical significance of correlation between components of the amber arthropod assemblage was assessed using $\chi^{2}$ test. For the direct assessment of correlations between syninclusion components, we used the ratio of the expected and observed shares of syninclusions with regard to their reliability. The expected share is calculated as the product of the actual shares of the components, i.e. the taxa forming the syninclusion, multiplied by each other. Values substantially exceeding unity indicate a positive correlation between the components, i.e. either the preference of the same conditions or their direct ecological interdependence, e.g. certain form of symbiotic relationships [Perkovsky et al., submitted]. When $\chi^{2}$ value is higher than 6.63 , the probability of an occasional coincidence of the respective events is less than 0.005 , and the difference between the observed and expected values is therefore termed highly significant.

\section{Results}

During the study of ant-Germaraphis syninclusions in the Kalandyk collection, we have unexpectedly revealed that this kind of co-occurrence was the most characteristic of the ant Prenolepis henschei Mayr, 1868 , the fifth in number in the Eocene ambers (as estimated by Dlussky and Rasnitsyn [2009]), and not of the most common amber ants $C$. goepperti and $L$. schiefferdeckeri (Table 1).

Five or six pieces of amber with the specimens of Prenolepis Mayr, 1861 weighted above $10 \mathrm{~g}$; and three out of those five pieces also contained four small Germaraphis larvae and two coccids as syninclusions (Table 1). An average weight of Prenolepis syninclusions with arthropods that could be identified to the order level was $14.4 \mathrm{~g}$. On the other hand, an average weight of Prenolepis-Germaraphis syninclusions was $11.9 \mathrm{~g}$, which was nearly equal to an average weight of the pieces with animal inclusions in the Kalandyk collection, i.e. $12.2 \mathrm{~g}$.

Ant-aphid syninclusions were also studied in the collection of the Rovno amber of Schmalhausen Institute of Zoology of NAS of Ukraine, Kiev (SIZK). We have found aphids in five out of 22 syninclusions $(22.7 \%)$ with ants from two different genera (see below).

Most pieces of the Rovno amber with Prenolepis inclusions were much smaller than those from the Kalandyk collection (see below). Syninclusions in those small pieces of amber were relatively rare (139 out of 1339 pieces of the Rovno amber [Perkovsky et al., 2010a, Table 4]), and ant-aphid syninclusions were 
Table 1. Syninclusions of Prenolepis henschei in the Kalandyk collection. Таблица 1. Состав сининклюзов янтарей с включениями Prenolepis henschei в коллекции Каландыка.

\begin{tabular}{|c|c|c|c|c|}
\hline $\begin{array}{l}\text { Inventory } \\
\text { number }\end{array}$ & Other syninclusions & $\begin{array}{l}\text { Prenolepis, } \\
\text { specimens }\end{array}$ & $\begin{array}{l}\text { Germaraphis, } \\
\text { specimens }\end{array}$ & $\begin{array}{l}\text { Weight, } \\
\mathrm{g}\end{array}$ \\
\hline 224 & $\begin{array}{l}\text { Aranei } \\
\text { Acari (Oribatei) } \\
\text { Coleoptera: Scraptiidae: Anaspidinae } \\
\text { Diptera: Dolichopodidae } \\
\text { Collembola, Arthropleona } \\
\end{array}$ & 1 & & 14.2 \\
\hline 816 & $\begin{array}{l}\text { Diptera: Chironomidae }-2 \text { females, male; } \\
\text { Sciaridae, male; } \\
\text { Ceratopogonidae: Forcipomyia, female; } \\
\text { larva } \\
\text { Collembola: Sminthuridae } \\
\text { Thysanoptera }-2 \\
\text { Acari (2, Oribatei - 1) } \\
\text { stellate hairs }\end{array}$ & 2 & 1 & 10.9 \\
\hline 1684 & $\begin{array}{l}\text { Acari (Oribatei) } \\
\text { stellate hairs }\end{array}$ & 2 & & 15.15 \\
\hline 1813 & $\begin{array}{l}\text { Diptera: Chironomidae, female; Cecidomyiidae; } \\
\text { larva } \\
\text { Coleoptera: Elateridae } \\
\text { Aranei } \\
\text { Coccinea } \\
\text { Collembola, Arthropleona } \\
\text { Acari (3, Oribatei - 1) }\end{array}$ & 1 & 2 & 13.85 \\
\hline 1905 & Leg of insect & 1 & & 3.7 \\
\hline 1920 & $\begin{array}{l}\text { Diptera: Sciaridae (2); Chironomidae, female } \\
\text { Acari }(3, \text { Oribatei }-1) \\
\text { Coccinea } \\
\text { Aranei }\end{array}$ & 1 & 1 & 17.7 \\
\hline
\end{tabular}

almost unique among small pieces of amber (with net weight less than $6.5 \mathrm{~g}$ [Perkovsky, 2010]). The sample SIZK K-25828 was the first known ant-aphid syninclusion in a small piece of the Rovno amber (Fig. 1).

\section{Discussion}

The ratio of the observed and expected shares of Prenolepis-Germaraphis syninclusions among 1824 pieces of amber with animal inclusions from the Kalandyk collection (Table 1$)$ is $16.888\left(\chi^{2}=46.365, \mathrm{P}<<\right.$ $0.001)$. Consequently, the probability of the occasional co-occurrence of those insects in the same piece of amber is extremely small. The high number of syninclusions therefore indicates the close relationship between Germaraphis and Prenolepis.

Longbeaked Germaraphis aphids were undoubtedly tended by ants. Thirteen out of 54 pieces with Germaraphis in the Kalandyk collection also contained ant inclusions (the ratio of the observed and expected shares of syninclusions of the worker ants and Germaraphis is 3.85:1). In addition to syninclusions shown in Table 1, Germaraphis aphids were found in five pieces of amber together with L. schiefferdeckeri (the ratio of the observed and expected shares for Lasius-Germaraphis syninclusions is $5: 1$ ), in four pieces with $C$. goepperti (the ratio of the observed and expected shares is 2.8:1), and in one piece with Formica flori Mayr, 1868. It is noteworthy that in all those cases the ratio of the observed and expected shares is relatively low if compared to that of Prenolepis-Germaraphis syninclusions.

In the Rovno amber, Prenolepis-Germaraphis syninclusions were unknown until recently. It should be noted that the share of Germaraphis itself among all insects (excluding Entognatha) in the Rovno amber is several times less than that in the Baltic amber from the Bay of Gdańsk [Perkovsky et al., 2007]. Until now, in SIZK collection of the Rovno amber there were 29 pieces with Prenolepis workers (as compared to six pieces in the Kalandyk collection), but only four pieces of the Rovno amber with Prenolepis were large enough. The other pieces were small (usually not exceeding the piece no. 1905 in the Kalandyk collection; Table 1), and rarely had Ectognatha as syninclusions. The antGermaraphis syninclusion that was found only in 2010 contains the thermally modified ant which "can belong only to Prenolepis among the known genera" [Dlussky, pers. comm.] (SIZK, specimen K-25828, net weight 1 g; Fig. 1). Another similar syninclusion of an aphid and the incomplete remains of Prenolepis (thermally unmodified in that particular case) in the Rovno amber is described below.

Prenolepis accounts for $6.2-6.7 \%$ of all ant specimens in the representative collections of the Baltic 


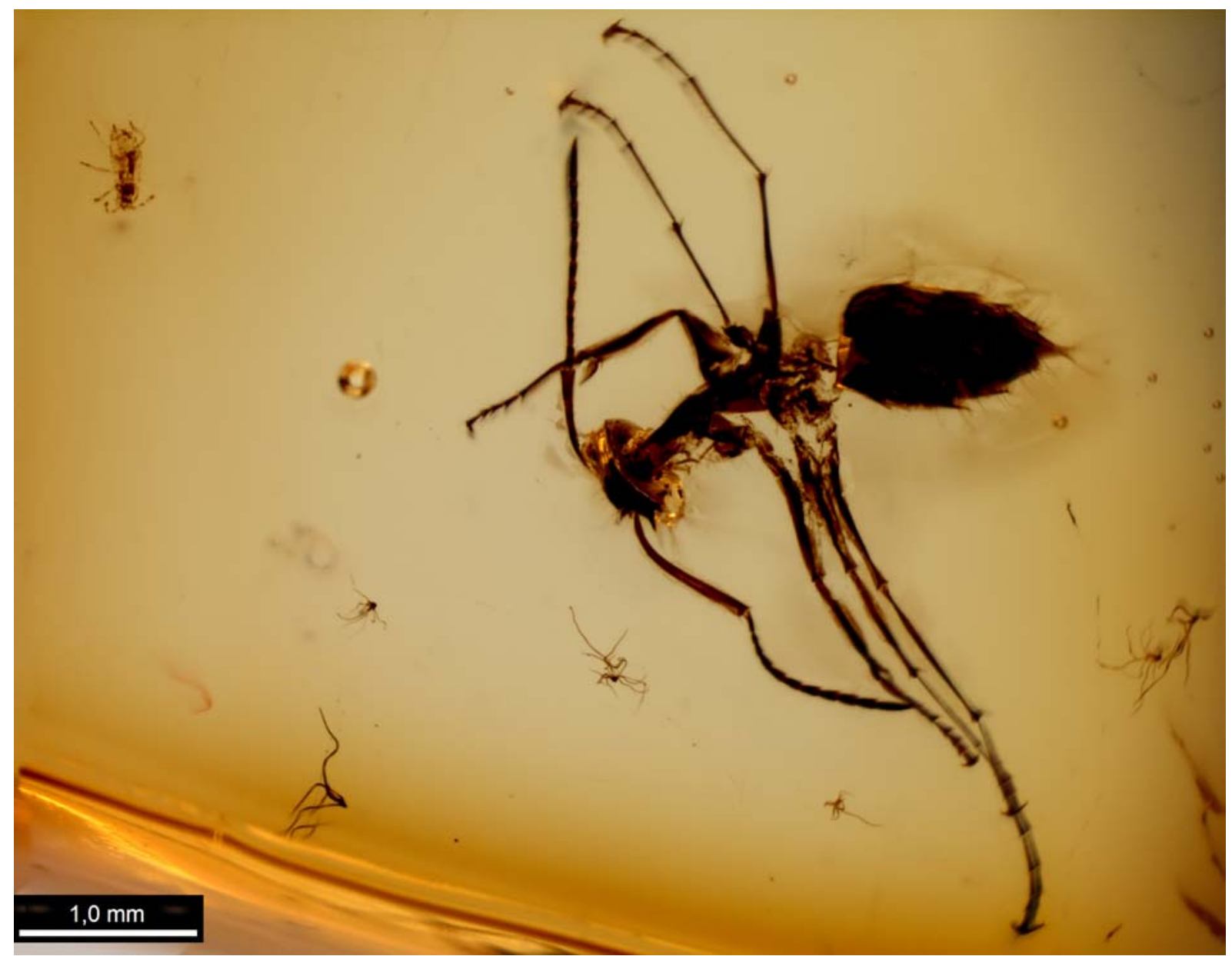

Fig.1. Prenolepis-Germaraphis syninclusion in a small piece of the Rovno amber (SIZK, K-25828).

Рис.1. Сининклюз Prenolepis и Germaraphis в мелком куске ровенского янтаря (коллекция Института зоологии НАН Украины; ИЗАНУ, К-25828).

amber, $6.3 \%$ in the Scandinavian amber (that is unique by having half of all specimens as males), 3.9\% in the Rovno amber, and $0.6 \%$ in the representative collection of the Bitterfeldian amber. Rarity of $P$. henschei in the amber from Bitterfeld can be explained by a very small size of the studied pieces of the Bitterfeldian amber with ant inclusions.

W.M. Wheeler [1930, p. 1] noted strong morphological similarity of $P$. henschei to Prenolepis imparis (Say, 1836) and P. nitens (Mayr, 1853) ("imparis ... is scarcely more than variety of extinct henschei"). The males of $P$. henschei and $P$. imparis are likewise remarkably similar, with an important difference in the structure of the parameres [La Polla, Dlussky, 2010]. Wheeler [1930] emphasized that neotropical and palaeotropical Prenolepis species "are quite different from the group comprising the very closely interrelated $\mathrm{im}$ paris, nitens and henschei". Mentioned modern species of this group are distributed in the Nearctic and West Palaearctic Regions. Consequently, this group together with the Late Eocene European ambers indicate that Prenolepis together with Formica Linnaeus,
1758 and Lasius Fabricius, 1804, is characteristic of the Palaearctic and Nearctic Regions. Latter genera are only scarcely represented in the tropical areas, where they are exclusively restricted to the mountains [Dlussky, Rasnitsyn, 2009].

Prenolepis imparis and $P$. nitens are very similar to each other in their ecology. The former species is the only Nearctic member of Prenolepis, also known as the false, winter or small honey ant. It is widely distributed, very common and well-studied. Winter ants initiate foraging when the temperature rises just above the freezing and discontinue this activity at about $26^{\circ} \mathrm{C}$ in Maryland [Lynch et al., 1980], and at $18.5^{\circ} \mathrm{C}$ in Missouri. They often build their nests deep underground staying inactive during the summer months. When the ants resume their activity during the cool season, they can forage even at $0^{\circ} \mathrm{C}$ and below, often being the only active ants. In North Florida, the ant is absent above the ground for 7 to 8 months, foraging only during the winter [Tschinkel, 1987] (e.g. for two months in north USA). However, their distribution range does not extend far to the North despite their tolerance to low 
temperatures [Wheeler, 1930]. Interestingly enough is that their range does not extend into the far north as might be expected from their cold tolerance. The distribution range of $P$. imparis almost precisely coincides with that of the oak [Wheeler, 1915, 1930]. Sexuals of $P$. imparis overwinter in the nests, and mating flights take place on the first warm day of spring [Tschinkel, 1987], towards the end of the season of the aboveground activity of the ants.

It was found that the winter ant is the most active at $15-19^{\circ} \mathrm{C}$ in Maryland; however, it is often also active at temperatures below $10^{\circ} \mathrm{C}$, while other ant species are the most active at $25-29^{\circ} \mathrm{C}$ and inactive at $10^{\circ} \mathrm{C}$ [Lynch et al., 1980]. In spring, P. imparis, in contrast to the other species, is the most active in the early morning. The unusual seasonal and circadian activity pattern of $P$. imparis results in a relatively low degree of the annual niche overlap between this species and its main competitors [Lynch et al., 1980]. This niche divergence might occur in the Late Eocene amber forests as well. The ability of Prenolepis foragers to individually collect up to $4 \mathrm{~g}$ of syrup could be their additional advantage [Lynch et al., 1980] because a single forager was therefore able to collect the entire honeydew crop from the colony of small Germaraphis larvae (having body length of 0.4 to $0.6 \mathrm{~mm}$ in the syninclusions with Prenolepis). The general aphid survey performed in Great Smoky Mountains National Park (Tennessee, North Carolina) showed that $P$. imparis tended six species of aphids, i.e. more than any other ant species except for Formica subsericea Say, 1836 [Favret et al., 2010]. The complete absence of myrmecophilous beetles in the nests of $P$. imparis [Wheeler, 1930] can probably be explained by the fact that the life cycle of the latter species significantly differs from those of a vast majority of other ants for a very long time.

Unlikely most native ants, $P$. imparis can survive in the presence of the invasive Argentine ant Linepithema humile (Mayr, 1868) from the subfamily Dolichoderinae [Sorrels et al., 2011]. P. imparis has been found to be relatively unaffected by the presence of $L$. humile due to the higher seasonal activity of $P$. imparis during the more cool and wet season when $L$. humile reduces its foraging intensity [Ward, 1987; Suarez et al., 1998; Sanders et al., 2001]. The coexistence of L. humile and $P$. imparis has been explained by the temporal niche separation, but it appears that $P$. imparis also has an effective defensive secretion [Sorrels et al., 2011]. $P$. imparis is therefore likely to have been preadapted for the competition with L. humile. The change in the seasonal activity in an ancestor of $P$. imparis was probably caused by the need to defend against very numerous and aggressive thermophilous ants. At present, this adaptation, together with the defensive secretion, allows $P$. imparis to successfully compete even with $L$. humile which is able to form so-called supercolonies.

Wheeler considered that foraging workers of $P$. imparis and $P$. nitens had greatly distended gasters [Wheeler, 1930, Fig. 3]. He also supposed that they were real "repletes" like those of the true honey ants of the Southwest USA and Mexico. However, W.R. Tschinkel [1987] ascertained that the gasters of those "replete" workers in fact contained enormously hypertrophied fat bodies, not accumulated carbohydrate solutions characteristic of the plerergates of the honey ants.

According to Tschinkel [1987], brood rearing by $P$. imparis in Florida during the summer highly depended on large amounts of fat and other nutrients stored by the corpulent workers. The weight of the corpulent (obese) workers ranged up to $8 \mathrm{mg}$ (with an average of $5.4 \mathrm{mg}$ ) and the weight of foragers was $2.0-2.2 \mathrm{mg}$ [Tschinkel, 1987]. In winter, foragers fed young (callow) workers. Corpulent young workers were losing their weight during the summer while rearing brood in the sealed nest, and they became foragers in winter, with their abdomens were not bloated any more. Those foragers had very dark body colour.

Gasters of some workers of the Priabonian Prenolepis henschei seem distended (Figs 2,3), but these ants are not corpulent. We believe that the life cycle of $P$. henschei could be similar to that of $P$. imparis. Callow workers of $P$. henschei have never been found, although individuals of this species are rather common (see above). Moreover, inclusions of callow workers of other common amber species are well-known, including those in the Rovno amber.

Similarity of the life cycles of $P$. henschei and $P$. imparis could explain the abundance of the males of $P$. henschei in certain representative collections, e.g., in the Scandinavian amber, where they are as numerous as the workers [La Polla, Dlussky, 2010]. The abundance of the male ants in amber is unusual and is also known only for the subfamily Ponerinae and Nylanderia pygmaea (Mayr, 1868) [Dlussky, Rasnitsyn, 2009; La Polla, Dlussky, 2010]. However, the situation with those groups is better explained by the scarcity of the workers rather then by the abundance of the alates. This is because of predominantly geobiotic foraging of the workers of the Ponerinae and Nylanderia pygmaea who rarely visited trees [Dlussky, Rasnitsyn, 2009]. On the contrary, this is less obvious for P. henschei, although we suggest a corresponding hypothesis that is given below.

Wheeler pointed out the unusual combination of "two distinct faunal components, one closely related to our present circumpolar, north temperate species, the other closely related to the tropical and subtropical species of Indomalayan and Australian Regions" [Wheeler, 1930, p. 14] in the myrmecofauna of the Baltic amber. This phenomenon could be explained by the low climatic seasonality in the first half of the Priabonian as compared to the modern times [Archiba1d, Farrell, 2003]. The detailed analysis of the above mentioned faunal components is given below. Wheeler [1930, Figs 1, 2] confirmed that $P$. imparis and $P$. nitens, on one hand, and the genus Liometopum Mayr, 1861 , on the other hand, have similar distribution in the 


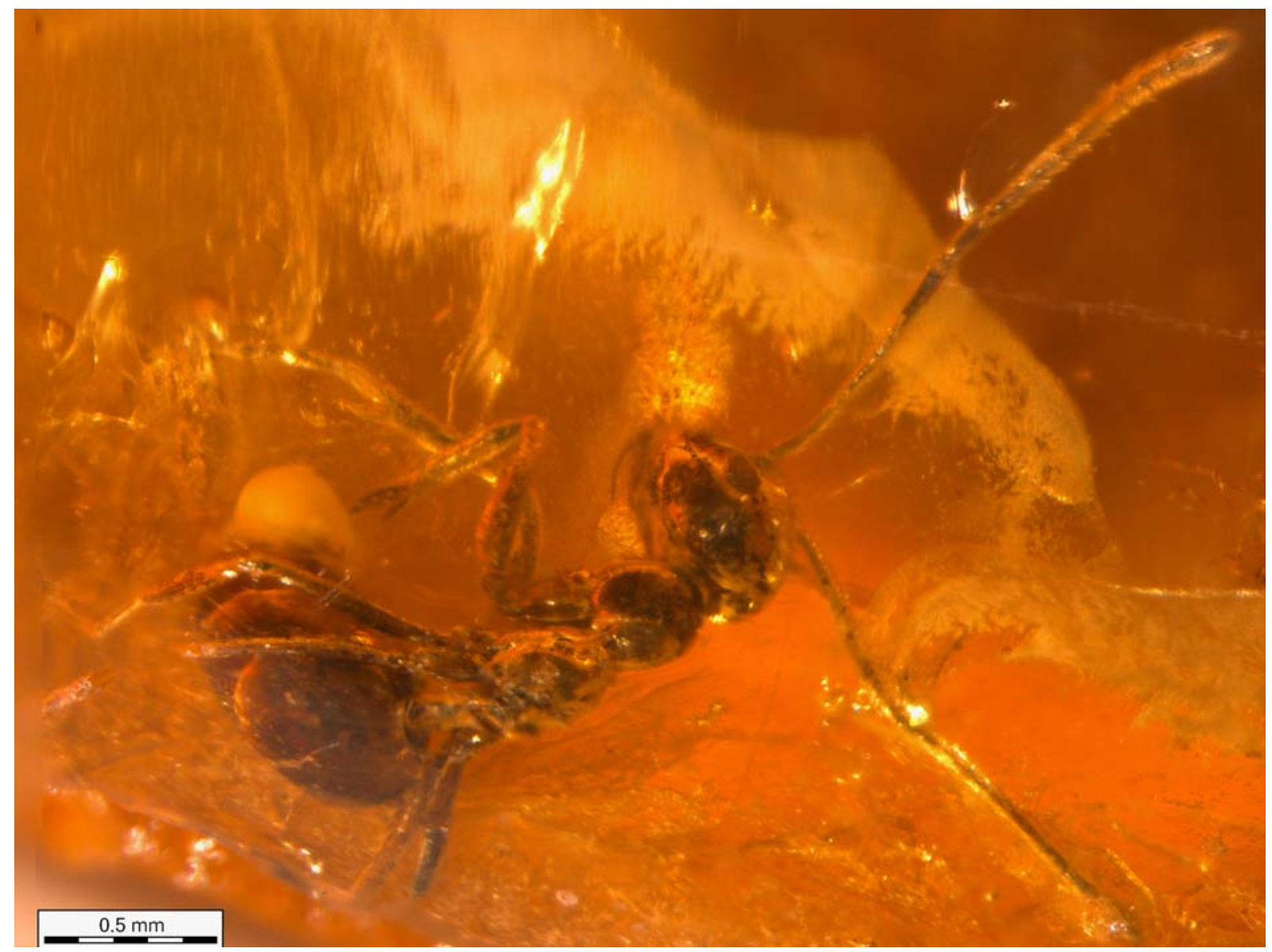

Fig.2. Prenolepis henschei in Baltic amber (the Kalandyk collection, No.1905 in the Museum of Amber Inclusions of the Department of Invertebrate Zoology, University of Gdańsk), dorsal view.

Рис.2. Prenolepis henschei в балтийском янтаре (коллекция Каландыка, №.1905 в Музее янтарных включений кафедры беспозвоночных Гданьского университета), вид сверху.

Nearctic and Western Palaearctic Regions. Liometopum is found in the Baltic amber and it was also a dominant species in the North American Florissant (terminal Eocene). It is associated with oak trees even more than P. imparis [Wheeler, 1930], and should also be considered as a temperate element in the Priabonian myrmecofauna. It is interesting that the European species of this genus is reported to have symbiotic relationship with Stomaphis aphids (like Lasius, see Petráková, Schlaghamerský, 2011). Moreover, distribution of modern species of the Plagiolepis pygmaea (Latreille, 1798) group is now limited to the Europe, Korea and Japan; four species of that group are recorded in the Late Eocene European ambers [Dlussky, 2010]. In addition, five species of the Dolichoderus quadripunctatus (Linnaeus, 1771) group are now distributed in the Europe, Asia Minor, Caucasus, Far East and North America [Dlussky, 2002]. Dlussky and Rasnitsyn [2009] refer to the genus Myrmica Latreille, 1804, together with Formica and Lasius, as Palaearctic groups. However, the recent revision [Radchenko, Elmes, 2010] reveals 62 Oriental endemics out of 142 Myrmica species known in the Old World. This genus therefore cannot be considered as the entirely Palaearctic group any more.

Species of Formica, Lasius, Prenolepis, Liometopum, the Plagiolepis pygmaea group, the Dolichoderus quadripunctatus group, and Stenamma Westwood, 1839 are considered here as "Holarctic" ("Palaearctic" sensu Dlussky and Rasnitsyn [2009]). Alternatively, there are 17 "tropical" genera, viz., 14 genera listed by Dlussky and Rasnitsyn [2009], together with Ochetellus Shattuck, 1992 (found in the Rovno amber, but with the present tropical distribution range) as well as with some undescribed members of the other genera from the Rovno amber, i.e. of Pachycondyla Smith, 1858 (now with predominantly tropical distribution, with a few exceptions [Yashiro et al., 2010]) and Pheidole Westwood, 1839 [Dlussky, pers. comm.]. The total species list of ants in the Rovno amber is updated to include a new species of Monomorium Mayr, 1855 [Radchenko, Perkovsky, 2009] as well as five additional undescribed members of other genera [Dlussky, Radchenko, pers. comm.]. As a result, the "Holarctic" 


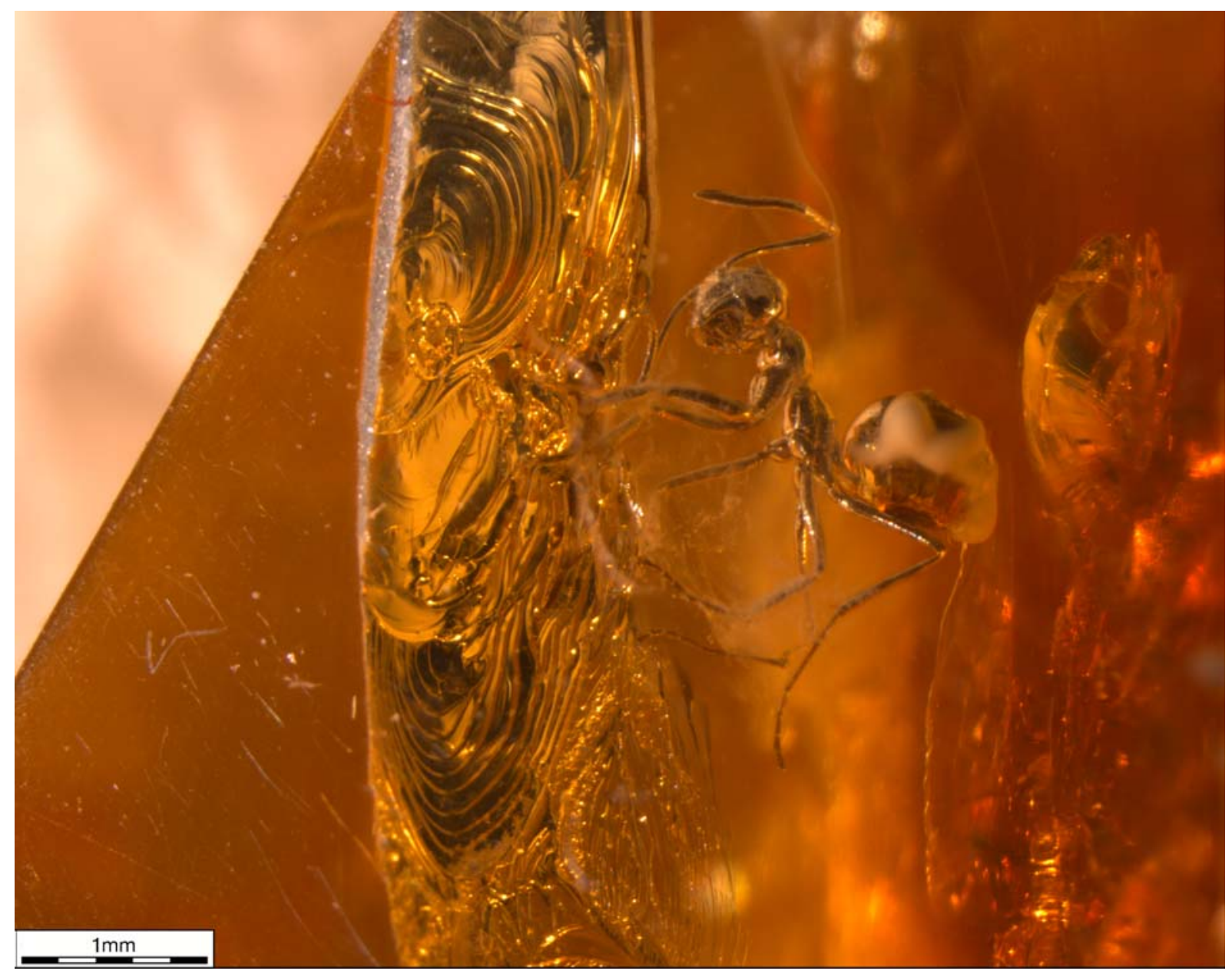

Fig.3. P. henschei in the Rovno amber (SIZK, K-7777), lateral view.

Рис.3. P. henschei в ровенском янтаре (коллекция Института зоологии НАН Украины; ИЗАНУ, К-7777), вид сбоку.

and "tropical" genera account for $21(16.9 \%)$ and 22 $(17.7 \%)$ species respectively out of 124 species in the Baltic amber, 12 (16.9\%) and 19 (26.8\%) species respectively out of 71 species in the Bitterfeldian amber, $7(18.9 \%)$ and $9(24.3 \%)$ species respectively out of 37 species in the Scandinavian amber, and $11(17.2 \%)$ and $17(26.6 \%)$ species respectively out of 64 species in the Rovno amber. In the Baltic amber, the number of species of the "tropical" genera is nearly the same as that of the "Holarctic" ones. However, it is 1.3 times more in the Scandinavian amber and 1.6 times more in the Bitterfeldian and Rovno ambers. Out of the five commonest ant species in the Late Eocene ambers, four species belong to modern genera, three of which are Holarctic and one is tropical. In terms of ant specimens found in the Late Eocene ambers, L. schiefferdeckeri is more numerous than all "tropical" ants combined [Dlussky, Rasnitsyn, 2009]. The abundance of the latter group is $3.2,3.3,3.8-9.4$ and 2.8 times less than that of the "Holarctic" species in the Rovno and Scandinavian ambers as well as in the representative collections of the Baltic amber and in the Berlin collection of the Bitterfeldian amber respectively. Since the propor- tion of L. schiefferdeckeri in the collections of amber ants strongly depends on the size of the pieces of amber [Perkovsky, 2009], we attempted to calculate the abundance of Holarctic genera excluding that species. With this exclusion, the ratio of specimens of the Holarctic vs. tropical genera is 2.3-3.6, 1.5, 1.2 and 0.9 in the representative collections of the Baltic amber, the Scandinavian and Rovno ambers as well as in the Bittefeldian amber (the representative collection of Humboldt Museum, Berlin) respectively.

The above results are likely to reflect respective climatic and geographic differences of the source areas of the respective ambers. Specifically, the Scandinavian amber comes from the South Swedish Eocene forest [Larsson, 1978]. Moreover, according to the palaeogeographic reconstructions by Popov et al. [2009], the southwestern part of the Fennoscandian Upland is the putative initial site of origin of the Scandinavian amber (with the subsequent southwestern drift). The territory of the large deposits of the Baltic amber near the present Bay of Gdańsk was occupied by deltas with a palaeochannel situated further to the North and with the subsequent drift to the South [Popov et al., 
2009]. The territory of the contemporary Baltic Sea (from Gotland to the West and the Gulf of Finland to the East) was represented by a plain. Huge stocks of the Baltic amber in Sambia suggest the former action of river flows from large territories of the eastern part of the Fennoscandian Upland that was situated further to the North (and more distant from the coast) than the putative sources of the Danish, i.e. Scandinavian, amber in Southern Scandinavia. The age and drift direction of the Bitterfeldian amber coincide with those of the eastern Baltic one [Ritzkowski, 1999]. This conclusion agrees with the low degree of difference between the faunas of those ambers, contrary to Dlussky and Rasnitsyn [2009]. The number of individuals of the ant species unknown from the eastern Baltic amber in the representative collection from Bitterfeld (Humboldt Museum) is as low as $1.5 \%$ of all ants identified to the genus level, in contrast to $5 \%$ in the Rovno amber and $8.3 \%$ in the Scandinavian one. As for the Rovno amber, its source area is located even further to the South, i.e. at the southern coast of Subparathetis (now Volyn Upland) [Perkovsky et al., 2010b].

The hypothesis of climatic differentiation between the above mentioned types of amber allows to understand the enigmatic distribution of the easily distinguishable myrmicine genus Fallomyrma Dlussky et Radchenko, 2006, which was never found in the best explored ant fauna of the Baltic amber, and comprises $1.1 \%$ of Rovno ants as the most abundant member of its subfamily and $6.9 \%$ of the Scandinavian ants (the third most abundant ant in that assemblage). This justifies an assumption that Fallomyrma represents another thermophilous ("tropical") ant genus that is absent from the Baltic amber due to climatic differences. Adding Fallomyrma to the list of the "tropical" ant genera increases their share up to $17.7,13.1,12$ and only 3.8$9.4 \%$ of ant specimens in the Scandinavian and Rovno ambers as well as in the representative collection from Bitterfeld at Humboldt Museum and in the representative collections of the Baltic amber from Sambia and Gdańsk respectively. The number of ant specimens belonging to those 18 genera is 1.1 times more than that of the Holarctic ones (excluding Lasius) in the Bitterfeldian amber. However, their numbers are equal in the Rovno and Scandinavian ambers, and "tropical" ants are 2.0-3.9 times less abundant than "Holarctic" ones in the Baltic amber [Dlussky, pers. comm.].

Certain features of the amber fossil assemblages are based only on their supposed geographic and climatic differences. One of the most striking facts among those features is the high abundance of the inclusions of stellate hairs from scales of the oak buds (that are shed off in spring) in place of the needles of the amber trees. Nevertheless, this situation can be explained if we suppose that the amber trees were represented by deciduous conifers (e.g. by species of Pseudolarix Gordon [Anderson, LePage, 1996]), and that those trees had the strictly time-limited season of the massive resin output which coincided with the flowering time of the oaks and predated that of the appearance of foliage of the amber trees. Moreover, this hypothesis allows to explain and reconcile a number of other observations. Specifically, the relative scarcity of workers and abundance of alate Prenolepis in the Rovno and Scandinavian ambers as compared to the Baltic and Bitterfeldian ones might depend on the different timing of the resin-producing period in respect to seasonal events of the ant life cycles. In the Scandinavian amber, the males of $P$. henschei comprise more than a quarter of all male ants (they are as numerous as the males of Nylanderia pygmaea), and this is also quite unusual for the Late Eocene ambers. The proportion of the workers of $P$. henschei in the Scandinavian and Rovno ambers, i.e. 2.8 [Dlussky, pers. comm.] and 3.5\% of all workers identified to the genus level respectively is significantly less than those characteristic of the large representative collections of the Baltic amber $(6.5-6.9 \%)$. It is important that the number of alates of $P$. henschei in the Scandinavian amber equals that of the worker ants. On the other hand, alates comprise $17.5 \%$ of all individuals of $P$. henschei in the Rovno amber and only $3.7 \%$ in the Baltic amber [La Polla, Dlussky, 2010]. For the latter case, the above figures are corrected according to the results of the last revision [La Polla, Dlussky, 2010]. These results show that only two gynes and a single male have been correctly identified as $P$. henschei by Wheeler [1915], whereas fifteen other gynes and males belong in fact either to $N$. pygmaea [La Polla, Dlussky, 2010] or even to Tapinoma aberrans Dlussky, 2002 [Dlussky, Rasnitsyn, 2009]. Consequently, G.M. Dlussky have found only eight alates (six males and two gynes) among 217 specimens of $P$. henschei in the Baltic amber including a single male in the two representative collections and two males (out of three specimens of $P$. henschei) in the carefully selected Carsten Gröhn collection [Dlussky, Rasnitsyn, 2009]. On the other hand, seven alates (six males and one gyne) and nine alates (only males) were found among 40 specimens of $P$. henschei in the Rovno amber and among 18 Prenolepis specimens in the Scandinavian amber respectively. The proportion of Prenolepis spp. among worker ants in the Scandinavian and Rovno ambers (decreasing by 1.9 times, as compared to the Baltic amber) is therefore accompanied by the increase of the share of their alates by 3.2 to 6.6 times.

We hypothesize that the abundance of the male burials in the Scandinavian and Rovno ambers could have been caused by the coincidence between the time of emergence of the males of $P$. henschei and the seasonal activity of resin traps. Since the only amber syninclusion of the gyne and male found in the Rovno amber appears to belong to $P$. henschei (among all other collections of the Late Eocene ambers, we are aware of the only other probable syninclusion of the ponerine gyne and male in the Scandinavian amber), it can be assumed that the abundance of sexuals of this species is really associated with swarming. In addition, the only syninclusion with the two alates of $P$. henschei 
is known among all other specimens of the Late Eocene ambers. In contrast, workers of $P$. henschei greatly outnumber their sexuals in the Baltic amber. This could be explained by the situation when the resin traps in the Baltic amber forest were active at lower temperatures, which was probably favourable for foraging (but not for swarming) of $P$. henschei.

Wheeler [1915] paid a considerable attention to the findings of the tropical and temperate ants as syninclusions in the same pieces of amber. However, all his examples of those syninclusions involved either individuals of Ctenobethylus Brues, 1939 as a tropical component (although its tropical nature is questioned now due to its similarity to or even synonymy with Liometopum), or the cases of co-occurrence of two tropical or two Holarctic genera. Nevertheless, findings of the tropical and temperate ants in the same syninclusions were confirmed by Dlussky [pers. comm.]. Specifically, there are four syninclusions of Iridomyrmex geinitzi (Mayr, 1868) in the Rovno amber, i.e. two with Formica spp., one with L. schiefferdeckeri and another one with Dolichoderus polessus Dlussky, 2002 from the Dolichoderus quadripunctatus group. The Bitterfeldian amber provides a syninclusion of Oecophylla Smith, 1860 with Lasius; the Baltic amber shows syninclusion of Gesomyrmex Mayr, 1868 with Formica (the same piece of amber also contains many Germaraphis aphids and coccids), two syninclusions of I. geinitzi together with Formica, and another one of I. geinitzi together with a species of the Plagiolepis pygmaea group. In addition, there are syninclusions of the extinct genera from the tropical tribes with the Holarctic ant genera, specifically Bradoponera Mayr, 1868 with Formica in the Bitterfeldian amber and with Lasius in the Baltic one as well as a syninclusion of Procerapachys Wheeler, 1915 with Lasius in the Baltic amber [Dlussky, pers. comm.]. However, Prenolepis was never found in syninclusions with any of the mentioned thermophilous ants either by Wheeler [1915] or Dlussky [pers. comm.]. In particular, the thermophilous ant Iridomyrmex geinitzi which is known by more than a thousand specimens, is the only one out of the five most common amber ants that has never been found in syninclusions with $P$. henschei. These observations imply effective thermal (most probably seasonal) divergence between the least and the most thermophilous ants in the Late Eocene amber forests. The cases of the two "Holarctic" genera are particularly instructive. The amber inclusions of Formica spp. are more numerous by one-third than those of Prenolepis, although they are recorded in five syninclusions with thermophilous ants (which constitutes one-third of all Formica syninclusions with other ants), while Prenolepis was never found in syninclusions of that kind [Dlussky, pers. comm.].

In addition to its cryophily, or negative thermotropism, there is another feature of the life history of $P$. imparis, i.e. its failure to keep root aphids or coccids in ant nests, unlike species of the genus Lasius and many other groups [Wheeler, 1930]. Nevertheless, Wheeler [1930] found that $P$. imparis can effectively utilize honeydew obtained from outside the nest due to its ability to develop "repletes". It is therefore not surprising that foragers of $P$. imparis from three different colonies gained an average of 130 to $200 \%$ of their original body weight while feeding with syrup [Lynch et al., 1980], and corpulent individuals converted carbohydrates to other reserve substances stored in their fat bodies.

Another unusual feature of Prenolepis is that syninclusions with more than one worker of $P$. henschei are very rare if compared with the abundance of that species in amber. Although more than 600 specimens of $P$. henschei were found up to now [Dlussky, Rasnitsyn, 2009], only ten syninclusions of two workers of $P$. henschei are known, specifically: two in the Kalandyk collection (see Table 1); three in the Museum of Earth, Warsaw; three in the Paleontological Institute, Moscow; one in the Zoological Museum of the University of Copenhagen (all in the Baltic amber), and another one in the Rovno amber (SIZK). Moreover, findings of more than two workers in the same piece of amber have never been recorded.

Interestingly, in the whole representative collection by Tadeusz Giecewicz (amber from the Western part of the Bay of Gdańsk in the collection of the Museum of Earth) there were only two pieces of amber (out of 24 pieces with $P$. henschei), each containing two workers. The Kalandyk collection with only six pieces of amber with this species (Table 1) also includes two pieces, each containing a pair of workers of $P$. henschei. We believe that this could be explained by the larger size of the pieces of amber in the Kalandyk collection.

At the same time, six syninclusions of $P$. henschei with other ant species are known only in the Rovno amber, i.e. two pieces of amber with C. goepperti (one of them, a large piece with a headless worker of Prenolepis, also contains Germaraphis), two with L. schiefferdeckeri, one with Formica sp. and another one with an undetermined ant. The collection of the Baltic amber of the Museum of Earth also has two syninclusions of the workers of $P$. henschei with $C$. goepperti and another one with Camponotus mengei Mayr, 1868 [Dlussky, pers. comm.].

Other ants of the Rovno and Baltic ambers are more common in syninclusions with the workers of their own species [Perkovsky, 2009]. This is probably explained by the fact that $P$. henschei, like $P$. imparis, and unlike other common ants of the Late Eocene ambers, neither kept aphids in their nests (which might result from the specific seasonal activity of Prenolepis), nor intensively exploited aphid colonies that are tended by ants having large families. Solitary foraging could therefore result in the individual burial of $P$. imparis in the resin traps. This also explains the situation when only one out of six ant syninclusions with the workers of $P$. henschei in the Rovno amber contains two workers of 
that particular species. Moreover, $P$. imparis, the extant counterpart of $P$. henschei, does not provide tree aphids with an effective protection. Specifically, tending by $P$. imparis does not affect the abundance of the aphids, in contrast to that by the Argentine ant $L$. $h u$ mile when the aphids double their amount under protection by the ants [Nygard et al., 2008]. Nygard et al. [2008] demonstrated that if aphid colonies were tended only by $P$. imparis, they disappeared in late spring due to destruction of the unprotected colonies in the absence of the ants.

A few solitary foragers are able to collect honeydew from small aphid colonies, especially because the foragers of $P$. imparis can keep large amounts of carbohydrates in their proventriculi (see above). On the other hand, large aphid colonies have to be protected by dominant ants living in large colonies themselves (see [Petráková, Schlaghamerský, 2011]). In the only one Rovno amber piece with Prenolepis containing three ants, two of them ( $P$. henschei and an undetermined ant) are represented by isolated head capsules. Moreover, the head capsule of $P$. henschei has only remained in a particular syninclusion with $L$. schiefferdeckeri. This could result from an antagonism between $P$. henschei and other amber ants. The antagonism between $P$. henschei and L. schiefferdeckeri could occur due to the defense of aphid colonies by the latter species against the foragers of the former one.

\section{Conclusions}

We assume that the ants Prenolepis henschei were not dendrobiotic and they foraged on amber trees mainly looking for homopterans (particularly aphids) which they did not keep in their nests. The ant $P$. henschei, similarly to $P$. imparis, could supported large aphid colonies nor recruited many workers for a small colony, because a single forager was able to collect sufficient volumes of honeydew from a small colony. The relationship between $P$. henschei and Germaraphis was not obligatory since it depended on the abundance of the aphids. Foragers of $P$. henschei could interfere with other common tree-visiting amber ants (including those keeping aphids in their nests), but generally managed to avoid their aggression due to alternative seasonal and circadian activities. This conclusion is supported by the rarity of syninclusions of $P$. henschei with other ant species in the Baltic amber as well as by the total absence of those with the thermophilous ants recorded from any Late Eocene European amber. Since their syninclusions with the conspecific workers are rare, this could indicate predominantly solitary foraging on the amber trees. The activity of the resin traps is supposed to be time-limited, and we hypothesize that they were active in the Baltic amber forest at the relatively lower temperatures as compared to those of the Scandinavian and Rovno amber forests. This hypothesis explains the low share of workers and the high numbers of males of $P$. henschei in the Scandinavian and
Rovno ambers compared to the Baltic one. In addition, we suppose that Prenolepis ants started to develop corpulent workers ("repletes") by the Late Eocene as the key adaptation to their unusual type of seasonal activity also known for modern $P$. imparis and that this allowed them to compete successfully with aggressive thermophilic ants.

\section{ACKNOWLEDGEMENTS}

The author is sincerely grateful to Dr. Sergey Rasnitsyn (Moscow) for calculating statistical data for the Prenolepis-Germaraphis syninclusions, to Prof. Gennady Dlussky (Moscow State University) for identifying ants, to Prof. Alexandr Rasnitsyn (Paleontological Institute, Moscow), Prof. Alexandr Radchenko (Institute of Zoology, Kiev) and to Prof. Ryszard Szadziewski (University of Gdańsk, Poland) for providing valuable discussion of the draft version of the paper. I am also very grateful to Prof. Szadziewski as well as to Dr. Elżbieta Sontag (University of Gdańsk, Poland) for their hospitality and opportunity to work with the Kalandyk collection in Gdańsk.

\section{References}

Anderson K.B., LePage B.A. 1996. Analysis of fossil resins from Axel Heiberg Island, Canadian Arctic // American Chemical Society Symposium Series. Vol.617. P.170-192.

Archibald B., Farrell B.D. 2003. Wheeler's dilemma // Acta zoologica cracoviensia. Vol.46. (Supplement. Fossil Insects). P.1723.

Dlussky G.M. 2002. Ants of the genus Dolichoderus (Hymenoptera: Formicidae) from the Baltic and Rovno ambers // Paleontological Journal. Vol.36. No.1. P.50-63.

Dlussky G.M. 2010. Ants of the genus Plagiolepis Mayr (Hymenoptera, Formicidae) from Late Eocene ambers of Europe // Paleontological Journal. Vol.44. No.5. P.546-555.

Dlussky G.M., Rasnitsyn A.P. 2009. Ants (Insecta: Vespida: Formicidae) in the Upper Eocene amber of Central and Eastern Europe // Paleontological Journal. Vol.43. No.9. P.1024-1042.

Heie O.E., Wegierek P. 2009. A classification of the Aphidomorpha (Hemiptera: Sternorrhyncha) under consideration of the fossil taxa // Redia. Vol.92. P.69-77.

Koteja J. 1989. Syninclusions // Wrostek. No.8. P.7-8.

Kutscher M., Koteja J. 2000. Coccids and aphids (Hemiptera: Coccinea, Aphidinea), prey of ants (Hymenoptera, Formicidae): evidence from Bitterfeld amber // Polskie Pismo Entomologiczne. Vol.69. No.2. P.179-185.

LaPolla J.S., Dlussky G.M. 2010. Review of fossil Prenolepis genus-group species (Hymenoptera: Formicidae) // Proceedings of the Entomological Society of Washington. Vol.112. No.2. P.258-273

Larsson S.G. 1978. Baltic amber - a paleontological study // Entomonograph. Vol.1. P.1-192.

Lynch J.F., Balinsky E.C., Vail S.G. 1980. Foraging patterns in three sympatric forest ant species, Prenolepis imparis, Paratrechina melanderi and Aphaenogaster rudis (Hymenoptera: Formicidae) // Ecological Entomology. Vol.5. P.353-371.

Nygard J.P., Sanders N.J., Connor E.F. 2008. The effects of the invasive Argentine ant (Linepithema humile) and the native ant Prenolepis imparis on the structure of insect herbivore communities on willow trees (Salix lasiolepis) // Ecological Entomology. Vol.33. P.789-795.

Perkovsky E.E. 2009. Differences in ant (Hymenoptera, Formicidae) species composition between weight fractions of Rovno Amber // Paleontological Journal. Vol.43. No.9. P.1087-1091. 
Perkovsky E.E. 2010. [Participation of Germaraphis aphids (Homoptera, Aphidinea) in weight fractions of the Rovno Amber and their syninclusions with ants] // Vestnik Zoologii. Vol.44. No.1. P.55-62 [in Russian, with English abstract].

Perkovsky E.E., Rasnitsyn A.P., Vlaskin A.P., Taraschuk M.V. 2007. A comparative analysis of the Baltic and Rovno amber arthropod faunas: representative samples // African Invertebrates. Vol.48. No.1. P.229-245.

Perkovsky E.E., Rasnitsyn A.P., Vlaskin A.P., Rasnitsyn S.P. 2010a Community structure in the amber forest as revealed by the study of the arthropod syninclusia in the Rovno amber (Late Eocene of Ukraine) // Acta Geologica Sinica. Vol.84. P.954 958.

Perkovsky E.E., Zosimovich V.Yu., Vlaskin A.P. 2010b. Rovno Amber // Penney D. (ed.). Biodiversity of fossils in amber from the major world deposits. Manchester: Siri Scientific Press. P.116-136.

Perrichot V., Girard V. 2009. A unique piece of amber and the complexity of ancient forest ecosystems // Palaios. Vol.24. No.3. P.137-139.

Petráková L., Schlaghamerský J. 2011. Interactions between Liometopum microcephalum (Formicidae) and other dominant ant species of sympatric occurrence // Community Ecology. Vol.12. No.1. P.9-17.

Popov S.V., Akhmetiev M.A., Lopatin A.V., Bugrova E.M., Sytchevskaya E.K., Shcherba I.G., Andreeva-Grigorovich A.S., Zaporozhets N.I., Nikolaeva I.A., Kopp M.I. 2009. [Paleogeography and biogeography of the northern Paratethys basins Part 1. Late Eocene - Early Miocene] // Trudy Paleontologicheskogo Instituta. Vol.292. Moscow: Nauchnyj mir. 200 pp. [in Russian].

Radchenko A.G., Elmes G.W. 2010. Myrmica ants (Hymenoptera, Formicidae) of the Old World. Fauna Mundi, Vol.3. Warszawa: Natura Optima Dux Foundation. 789 pp.

Radchenko A.G., Perkovsky E.E. 2009. Monomorium kugleri n. sp., a new fossil ant species (Hymenoptera: Formicidae: Myrmicinae) from the late Eocene Rovno Amber (Ukraine) // Israel Journal of Entomology. Vol.39. P.99-103.

Rasnitsyn A.P. 2011. Arthropods in amber and other resins, both extant and extinct: recent results obtained at the Paleontological Institute, RAS, Moscow, Russia. // Amberif 2011. The 18th seminar on research on amber and its zoological inclusions.
Gdańsk. P.7-14.

Ritzkowski S. 1999. Das geologische Alter der Bernsteinführenden Sedimente in Sambia (Bezirk Kalinigrad), bei Bitterfeld (Sachsen-Anhalt) und bei Helmstedt (SE-Niedersachsen) // Investigation into Amber. Gdańsk. S.33-40.

Sanders N.J., Barton K.E., Gordon D.M. 2001. Long-term dynamics of the distribution of the invasive Argentine ant, Linepithema humile, and native ant taxa in Northern California // Oecologia. Vol.127. No.1. P.123-130.

Sontag E. 2003. Animal inclusions in a sample of unselected Baltic amber // Acta zoologica cracoviensia. Vol.46 (Supplement. Fossil Insects). P.431-440.

Sorrells T.R., Kuritzky L.Y., Kauhanen P.G., Fitzgerald K., Sturgis S.J., Chen J., Dijamco C.A., Basurto K.N., Gordon D.M. 2011. Chemical defence by the native winter ant (Prenolepis imparis) against the invasive Argentine ant (Linepithema humile) // PLoS One. Vol.6. No.4. P.e18717.

Suarez A., Bolger D.T., Case T. 1998. Effects of fragmentation and invasion on native ant communities in coastal Southern California // Ecology. Vol.79. No.6. P.2041-2056.

Tschinkel W.R. 1987. Seasonal life history and nest architecture of a winter-active ant, Prenolepis imparis // Insectes Sociaux. Vol.34. No.3. P.143-164.

Ward P.S. 1987. Distribution of the introduced Argentine ant (Iridomyrmex humilis) in natural habitats of the Lower Sacramento Valley and its effects on the indigenous ant fauna // Hilgardia. Vol.55. No.2. P.1-16.

Weitschat W. 2009. Jäger, Gejagte, Parasiten und Blinde Passagiere - Momentaufnahmen aus dem Bernsteinwald // Denisia. Vol.26. P.243-256.

Wheeler W.M. 1915. The ants of the Baltic Amber // Schriften der Physikalisch-Ökonomischen Gesellschaft zu Königsberg. Vol.55. P.1-142.

Wheeler W.M. 1930. The ant Prenolepis imparis Say // Annals of the Entomological Society of America. Vol.23. No.1. P.1-26.

Wichard W. 2009. Taphozönosen im Baltischen Bernstein // Denisia. Vol.26. P.257-266.

Yashiro T., Matsuura K., Guénard B., Terayama M., Dunn R.R. 2010. On the evolution of the species complex Pachycondyla chinensis (Hymenoptera: Formicidae: Ponerinae), including the origin of its invasive form and description of a new species // Zootaxa. Vol.2685. P.39-50. 